\title{
Factors Affecting the Changes in Amphotericin Sensitivity of Candida albicans during Growth
}

\author{
By E. F. GALE, ALISON M. JOHNSON, D. KERRIDGE \\ AND T. Y. KOH \\ Sub-department of Chemical Microbiology, Department of Biochemistry, \\ University of Cambridge, Cambridge $C B 2$ I $Q W$
}

(Received 23 July 1974)

\section{SUMMARY}

The sensitivity of Candida albicans, grown in batch culture at $37^{\circ} \mathrm{C}$, to amphotericin methyl ester (AME), judged by the concentration of AME required to induce a standard rate of leakage of $\mathrm{K}^{+}$from suspensions of organisms, decreased with the time of growth. Organisms in exponential growth were sensitive to $0 \cdot I$ to $0.2 \mu \mathrm{g} \mathrm{AME} / \mathrm{ml}$ while organisms in the stationary phase were resistant to 4 to $60 \mu \mathrm{g} \mathrm{AME} / \mathrm{ml}$, depending on the initial concentration of glucose in the medium and the length of time for which incubation had been continued. When the initial concentration of glucose was low $(0.1 \%, w / v)$, the AME resistance rose during the early stationary phase and then, after $40 \mathrm{~h}$ incubation at $37^{\circ} \mathrm{C}$, decreased again. Sphaeroplasts were prepared from organisms at different phases of growth and did not show these changes in AME sensitivity, but remained highly sensitive for growth up to $40 \mathrm{~h}$.

Sphaeroplasts were prepared by treating suspensions of organisms with mercaptoethanol and then digesting with Streptomyces enzyme preparation. Addition of the material extracted by the digestion to suspensions of exponential-phase organisms or sphaeroplasts increased their AME resistance. Fractionation of the digest showed that the antagonistic material was contained in the neutral lipid fraction. Pure lipids fell into the following order of decreasing antagonism to AME when added together with the antibiotic to suspensions of exponential-phase organisms: sterol esters (ergosterol esters > cholesterol esters; unsaturated fatty acid esters $>$ saturated fatty acid esters), sterols, triglycerides, unsaturated fatty' acids, saturated fatty acids. The amount of antagonistic material released from stationary organisms was not markedly greater than that from exponential-phase organisms and analysis of the lipid content of wall preparations showed that the content of total lipid, neutral lipid and triglyceride of $40 \mathrm{~h}$ organisms was not more than 75,25 and $30 \%$, respectively, greater than that of exponential-phase organisms.

The AME resistance of stationary-phase organisms decreased rapidly if suspensions were incubated with glucose or mercaptoethanol. The decrease in the presence of glucose was prevented by metabolic inhibitors, especially SH binding agents. Treatment of organisms with either iodoacetamide or $N$-ethylmaleimide gave a rapid increase in AME resistance, amounting in some cases to 5- to 15 -fold. The effect of iodoacetamide decreased as the organisms passed into the stationary phase and their intrinsic resistance increased. Evidence is presented which suggests that the degree of reduction of SH groups in the cell surface is an important factor in determining AME resistance.

\section{INTRODUCTION}

Polyene antibiotics alter the permeability of the plasma membranes of eukaryotic cells by interacting with sterols. All polyenes so far tested induce leakage of potassium ions from sensitive cells and Gale (1974) has used a potassium-sensitive electrode to monitor the damage 
produced in the membranes of Candida albicans by the presence of amphotericin methyl ester (AME) and other polyene antibiotics. The sensitivity of organisms harvested from a batch culture was found to vary markedly with the phase of growth; organisms harvested during the exponential phase of growth were sensitive to $0.2 \mu \mathrm{g} \mathrm{AME} / \mathrm{ml}$, but once the stationary phase was reached sensitivity decreased sharply, organisms harvested after $24 \mathrm{~h}$ at $37{ }^{\circ} \mathrm{C}$ requiring $2.4 \mu \mathrm{g} \mathrm{AME} / \mathrm{ml}$ for a similar response. We show that these changes in sensitivity are not found in sphaeroplasts derived from organisms harvested at different growth phases, but that major factors in determining the sensitivity of the whole organism are the structure and composition of the cell wall. While this work was in progress Hammond \& Kliger (1974) reported that protoplasts of $C$. albicans do not show changes in polyene sensitivity corresponding to those of the organisms from which they are derived. They observed that the cell wall is thicker in organisms in the stationary phase of growth than in those in the exponential phase, and proposed that the wall acts as a diffusion barrier towards the polyenes.

\section{METHODS}

Organism and growth conditions. Candida albicans 6406 was obtained from the Mycology Reference Laboratory of the London School of Hygiene and was maintained, cultured and prepared in washed suspension as previously described (Gale, 1974). Unless otherwise stated the growth medium contained $6.7 \mathrm{~g}$ Bacto yeast nitrogen (YNB) medium with glucose added to an initial concentration of $2 \%(\mathrm{w} / \mathrm{v})$.

Estimation of $K^{+}$release and AME sensitivity. The terms 'AME sensitivity' and 'AME resistance' in this paper refer to the action of amphotericin methyl ester hydrochloride in inducing the leakage of $\mathrm{K}^{+}$from suspensions of organisms (Gale, 1974). $\mathrm{K}^{+}$was estimated as previously described (Gale, 1974) by the use of a $\mathrm{K}^{+}$-sensitive electrode. Organisms were suspended at a final density of $1.0 \mathrm{mg}$ dry wt $/ \mathrm{ml}$ in $0.3 \mathrm{M}$-tris- $\mathrm{HCl}$ buffer $\mathrm{pH} 7.5$ at $20^{\circ} \mathrm{C}$. Since the experiments with sphaeroplasts required the presence of $0.8 \mathrm{M}$-sorbitol as osmotic stabilizer, this was included in the tests described unless otherwise stated. The rate of $\mathrm{K}^{+}$ release, above that of the control without drug, was followed until the standard rate of release (s.r.) equal to $\mathrm{I} \mathrm{nmol} \mathrm{K}^{+} / \mathrm{min} / \mathrm{mg}$ dry wt organisms above that in the control without drug, was obtained, and either the time taken to reach this rate of release (s.r.t.) or the concentration of AME needed to induce this rate in $8 \mathrm{~min}$ at $20^{\circ} \mathrm{C}$ (s.r.c.) was determined.

Antagonism. The previous studies showed that the product AME concentration $\times$ s.r.t. was approximately constant, so that halving the drug concentration doubled the value of s.r.t. To quantify the action of antagonistic substances, an antagonistic unit (a.u.) has been defined as that amount of material which doubles the time taken to reach the standard rate of release in the presence of s.r.c. S.r.c. $(8 \mathrm{~min})$ is first determined, the time taken to attain s.r. then determined in the presence of a range of antagonist concentrations and the same drug concentration, and the concentration of antagonist giving s.r.t. $=\mathrm{I} 6 \mathrm{~min}$ then found.

Sphaeroplast formation. Sphaeroplasts were prepared from intact organisms by use of the lytic enzyme preparation from Streptomyces violaceus, a modification of the method of Elorza, Munroz-Ruiz \& Villanueva (1966) being used. Sphaeroplasts can be produced readily from $C$. albicans harvested in the exponential phase of growth but modification, as below, in the enzyme preparation and the addition of mercaptoethanol are necessary for rapid and quantitative formation of sphaeroplasts from organisms harvested in the stationary phase of growth.

For treatment A, of early exponential-phase organisms, the lytic enzyme preparation was produced by growth of $S$. violaceus in the presence of chitin. Candida albicans was harvested, 
washed once each with $0 . \mathrm{I}$ and $0.9 \mathrm{M}$-sorbitol and resuspended at a density of $\mathrm{I} O \mathrm{mg}$ dry wt/ $\mathrm{ml}$ in $0.9 \mathrm{M}$-sorbitol and $\mathrm{O} . \mathrm{I} \mathrm{M}$-ammonium bicarbonate containing $0.0 \mathrm{I} \mathrm{M}$-mercaptoethanol. The suspension was incubated at $37^{\circ} \mathrm{C}$ for $30 \mathrm{~min}$, washed once with $0.9 \mathrm{M}$-sorbitol, and resuspended at 10 to $15 \mathrm{mg}$ dry $\mathrm{wt} / \mathrm{ml}$ in $0.5 \mathrm{M}$-imidazole buffer $\mathrm{pH} 6.8$ containing $0.9 \mathrm{M}$ sorbitol and the streptomyces enzyme preparation as described by Elorza et al. (I966). The mixture was incubated at $37^{\circ} \mathrm{C}$ and sphaeroplasts were formed within $\mathrm{I} h$, the process being followed by examination of samples under the microscope. The sphaeroplasts were harvested by centrifuging at $600 \mathrm{~g}$ for $10 \mathrm{~min}$ at $4{ }^{\circ} \mathrm{C}$, washed once with $0.9 \mathrm{M}$-sorbitol and resuspended at $\mathrm{I} 0 \mathrm{mg}$ dry wt original organisms $/ \mathrm{ml}$ in $0.05 \mathrm{M}$-tris- $\mathrm{HCl}$ buffer $\mathrm{pH} 7.5$ containing $0.8 \mathrm{M}$ sorbitol.

For treatment B, of late exponential- or stationary-phase cells, the lytic enzyme preparation was obtained by growing $S$. violaceus in the presence of $C$. albicans harvested in the late stationary phase and boiled; the enzyme preparation so obtained was mixed with an equal amount of the preparation from $S$. violaceus grown in the presence of chitin as above. The concentration of mercaptoethanol in the incubation mixture was increased to $0.2 \mathrm{M}$. Incubation with enzymes was continued for $3 \mathrm{~h}$ or longer at $37^{\circ} \mathrm{C}$; organisms harvested after $40 \mathrm{~h}$ at $37^{\circ} \mathrm{C}$ were converted to sphaeroplasts within $3 \mathrm{~h}$ but organisms harvested after longer incubation were found to require up to $6 \mathrm{~h}$ for complete conversion.

Sphaeroplasts prepared as above were diluted $\mathrm{I}: 9(\mathrm{v} / \mathrm{v})$ in $0.05 \mathrm{M}$-tris- $\mathrm{HCl}$ buffer $\mathrm{pH} 7.5$ containing $0.8 \mathrm{M}$-sorbitol for the $\mathrm{K}^{+}$release experiments described below.

Preparation of cell walls. Organisms grown to the appropriate density for the required period were harvested and washed twice with cold $0.5 \mathrm{M}$-imidazole buffer $\mathrm{pH} 6.8$ by centrifuging at $\mathrm{I} 2000 \mathrm{~g}$ at $4{ }^{\circ} \mathrm{C}$ for $5 \mathrm{~min}$. They were resuspended in the same buffer at densities of $200 \mathrm{mg}$ dry $w \mathrm{t} / \mathrm{ml}$, and $20 \mathrm{ml}$ portions were homogenized for $45 \mathrm{~s}$ with $50 \mathrm{~g}$ glass beads $(0.45$ to $0.50 \mathrm{~mm})$ in a Braun homogenizer (B. Braun, Germany) cooled with $\mathrm{CO}_{2}$. Efficiency of breakage was checked by microscopy. If homogenization was incomplete, the homogenates were filtered through a sintered glass filter (porosity 2) and the filtrate centrifuged at $600 \mathrm{~g}$ for ro min. The pellets were resuspended to 0.6 of the homogenization volume with buffer, homogenized again for $45 \mathrm{~s}$ and filtered as described. Over $99.9 \%$ of the organisms were broken by this procedure, DNA was digested with traces of DNAase, and the cell envelopes were washed at least six times with cold buffer by centrifugation at $600 \mathrm{~g}$ for $\mathrm{Io}$ min at $4{ }^{\circ} \mathrm{C}$ until the supernatant was clear and the envelope fraction was homogenous as observed under phase-contrast microscopy. The resultant cell envelope was further washed with cold distilled water and the pellet freeze-dried for analysis.

Extraction of lipids from cell envelopes. Cell envelopes were resuspended in 2 to $10 \mathrm{ml}$ water by sonication and 20 volumes of chloroform:methanol $(2: \mathrm{I}, \mathrm{v} / \mathrm{v})$ were added; the mixture was extracted under $\mathrm{N}_{2}$ with stirring at $30{ }^{\circ} \mathrm{C}$ for $2 \mathrm{~h}$. The extract was filtered with a glass-fibre filter and the residues re-extracted twice with 50 to $100 \mathrm{ml}$ of the organic solvent as above. The extracts were pooled and purified as described below.

Preparation and fractionation of the enzyme digest. For analysis of the digest supernatant, digestion was carried out for $3 \mathrm{~h}$ at $37^{\circ} \mathrm{C}$ unless otherwise stated, sphaeroplasts were removed, and the supernatant was further centrifuged at $22000 \mathrm{~g}$ for $20 \mathrm{~min}$ to remove particulate material and lipid granules released as a result of any lysis occurring during digestion. The supernatant (Table I, stage A) was heated at $100{ }^{\circ} \mathrm{C}$ for 10 min to inactivate lytic enzymes and further centrifuged at $22000 \mathrm{~g}$ for $10 \mathrm{~min}$ to separate precipitated material and a translucent liquid (Table I, stage B). The supernatant was extracted three times with an equal volume of chloroform-methanol $(2: \mathrm{I}, \mathrm{v} / \mathrm{v})$ to remove lipids (Table I, stage C); the $22000 \mathrm{~g}$ pellet was suspended in a small volume of water and lipid extracted by shaking with 


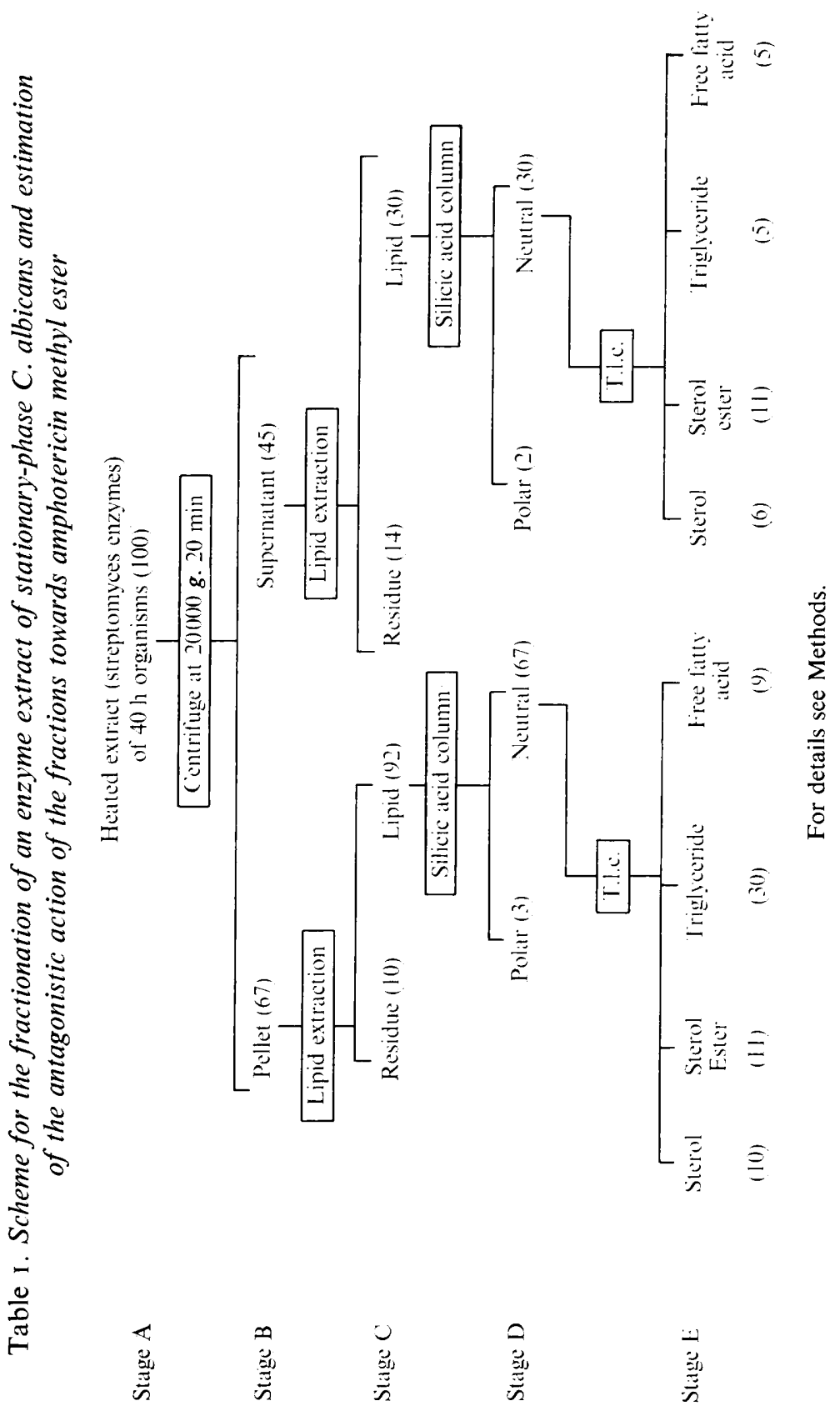


$20 \mathrm{vol}$. chloroform-methanol $(2: \mathrm{I}, \mathrm{v} / \mathrm{v})$; solid residues were further extracted twice for lipids. The lipid extracts were dried at $40{ }^{\circ} \mathrm{C}$ in vacuo and dissolved in ethanol for activity tests.

Lipid extracts were purified by passage through a column of Sephadex G25 (Wells \& Dittmer, 1963) and then fractionated into neutral and polar lipids (Table I, stage D) by using silicic acid by the method of Vorbeck \& Marinetti (I965). The neutral lipid was further separated (Table I, stage E) into sterol, sterol ester, triglyceride and free fatty-acid fractions by thin-layer chromatography on Kieselgel G (E. Merck, Darmstadt, Germany) using as solvent light petroleum (60 to $80^{\circ} \mathrm{C}$ fraction), diethylether and formic acid in the proportions 90: 10: I (by vol.) Lipids were located on thin-layer plates by charring an end strip with chromic acid spray. Each of the lipid bands was scraped off the plates, eluted with chloroform, dried at $40{ }^{\circ} \mathrm{C}$ in a rotary evaporator and resuspended in $96 \%$ ethanol for measurements of antagonistic activity.

Quantitative assay of lipids. Ergosteryl esters were estimated by absorption at $281.5 \mathrm{~nm}$ in chloroform solution: calibration was effected by reference to ergosteryl oleate. Ergosterol was estimated by absorption at $28 \mathrm{I} \cdot 5 \mathrm{~nm}$ of solutions in chloroform and also by the colorimetric method of Moore \& Baumann (I952). Total sterol was determined by gas-liquid chromatography (Vandenheuvel \& Sallycourt, I968) on a JXR column (supplied by Pye Unicam, Cambridge), at $240^{\circ} \mathrm{C}$ using ergosterol as internal standard. Free fatty acids were determined by the method of Heinen \& De Vries (1966), oleic acid being used as standard. Triglycerides were determined by the method of Van Handel \& Zilversmit (1957) using glycerol trioleate as standard. Lipid fractions were also determined by direct weighing of eluates from t.l.c. plates.

Materials. Amphotericin methyl ester was a gift from Professor C. P. Schaffner of Rutgers University, U.S.A. Ergosterol, cholesterol palmitate, oleic acid and linoleic acid were purchased from Sigma, cholesteryl oleate, palmitic acid, glyceryl trioleate and glyceryl dipalmitate from $\mathrm{BDH}$, and myristic acid, palmitoleic acid and stearic acid from Hormel Institute, Austin, Minnesota, U.S.A.

Ergosterol esters were prepared by the method of Kuksis \& Beveridge (I960). The products were recrystallized from benzene by the addition of methanol and their purity checked by t.l.c. as above. Ultraviolet spectra of the products were similar to that of ergosterol.

Incubation media $S$ and $N$. Medium S consisted of $0.4 \%(\mathrm{w} / \mathrm{v}) \mathrm{KH}_{2} \mathrm{PO}_{4}$ adjusted with $20 \%$ $(\mathrm{w} / \mathrm{v}) \mathrm{NaOH}$ to $\mathrm{pH} 6.3$ or other values as below. Medium $\mathrm{N}$ consisted of medium $\mathrm{S}$ diluted with an equal volume of ammonium phosphate solution [0.5 $\mathrm{g} \mathrm{NH}_{4} \mathrm{H}_{2} \mathrm{PO}_{4}+\mathrm{I} \cdot 5 \mathrm{~g}\left(\mathrm{NH}_{4}\right)_{2}{ }^{-}$ $\mathrm{HPO}_{4} / 1$. Glucose was added where indicated to final concentrations ranging from $\mathrm{O} \cdot \mathrm{I}$ to $2 \cdot 0 \%(\mathrm{w} / \mathrm{v})$.

\section{RESULTS}

Effect of age of culture on AME sensitivity of organisms and sphaeroplasts

Gale (1974) found that $C$. albicans harvested during exponential growth was very sensitive to AME but became progressively less sensitive as the culture passed into stationary phase. In terms of the s.r.c. of AME, sensitivity of organisms harvested after 5 h growth in a medium initially containing $0.1 \%$ glucose was $0.2 \mu \mathrm{g} \mathrm{AME} / \mathrm{ml}$, while that of organisms harvested after $24 \mathrm{~h}$ growth was $2.5 \mu \mathrm{g} / \mathrm{ml}$. Figure I shows that if incubation was continued well after the culture was in stationary phase, the sensitivity decreased to Io to I I $\mu \mathrm{g}$ AME/ $\mathrm{ml}$ after $36 \mathrm{~h}$ and then rose again until it sometimes approached that of exponential cells after 48 to $50 \mathrm{~h}$ incubation. Glucose at an initial concentration of $0 . \mathrm{I} \%$ was exhausted after approximately $\mathrm{I} 2 \mathrm{~h}$ growth. Table 2 shows that higher initial concentrations of glucose gave 


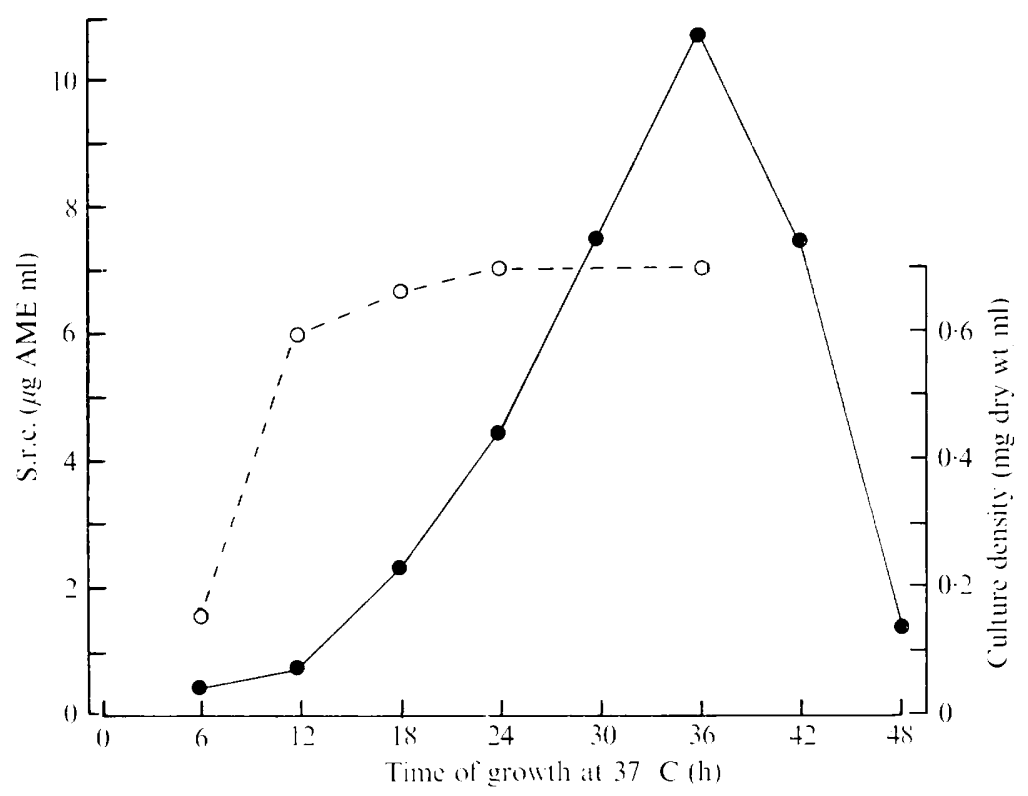

Fig. I. Variation of AME sensitivity of C. albicans with culture time. Candida albicans was grown at $37^{\circ} \mathrm{C}$ in YNB medium containing an initial glucose concentration of $0.1 \%(\mathrm{w} / \mathrm{v})$; organisms were harvested at $6 \mathrm{~h}$ intervals as shown, washed twice with distilled water and suspended at $\mathrm{I} \cdot \mathrm{O} \mathrm{mg}$ dry $\mathrm{wt} / \mathrm{ml}$ in $0.03 \mathrm{M}$-tris- $\mathrm{HCl}$ buffer $\mathrm{pH} 7.5$ for determination of s.r.c. (O) of AME. Culture density (O) was determined turbidimetrically in a Hilger Absorptioneter (Rank Frecision Industries Ltd, Margate, Kent) calibrated against C. albicans 6406.

Table 2. Effect of initial glucose concentration in growth medium on the AME sensitivity of late stationary-phase cultures of Candida albicans

Candida albicans was grown for 40 and $48 \mathrm{~h}$ at $37^{\circ} \mathrm{C}$ in YNB medium $(6.7 \mathrm{~g} / 1)$ containing initial concentrations of glucose as below. Cells were harvested, washed twice with distilled water on the centrifuge, and suspended in the electrode vessel at a final density of $\mathrm{I} \cdot 0 \mathrm{mg}$ dry $\mathrm{wt} / \mathrm{ml}$ in $0.03 \mathrm{M}$ tris- $\mathrm{HCl}$ buffer $\mathrm{pH} 7.5$ (in $0.8 \mathrm{M}$-soritol) for the determination of the s.r.c.

\begin{tabular}{|c|c|c|c|c|c|}
\hline \multirow[b]{4}{*}{$\begin{array}{c}\text { Initial } \\
\text { glucose } \\
(\%, w / v)\end{array}$} & \multicolumn{5}{|c|}{ Age of culture (h) } \\
\hline & \multirow[b]{3}{*}{$\begin{array}{l}\text { Culture } \\
\text { density } \\
(\mathrm{mg} / \mathrm{ml})\end{array}$} & 40 & & \multicolumn{2}{|c|}{48} \\
\hline & & \multicolumn{2}{|c|}{ S.r.c. $(\mu \mathrm{g} \mathrm{AME} / \mathrm{ml})$} & \multirow[b]{2}{*}{$\begin{array}{c}\text { Culture } \\
\text { density } \\
(\mathrm{mg} / \mathrm{ml})\end{array}$} & \multirow{2}{*}{$\begin{array}{c}\text { S.r.c. of } \\
\text { freshly } \\
\text { harvested } \\
\text { organisms } \\
(\mu \mathrm{g} \mathrm{AME} / \mathrm{ml})\end{array}$} \\
\hline & & $\begin{array}{l}\text { Freshly- } \\
\text { harvested } \\
\text { organisms }\end{array}$ & $\begin{array}{c}\text { IAM- } \\
\text { treated } \\
\text { organisms* }\end{array}$ & & \\
\hline 0.1 & 0.6 & $I \cdot 6$ & 8 & 0.6 & $I \cdot 4$ \\
\hline 0.3 & 0.9 & $2 \cdot 4$ & 6 & 0.9 & 8 \\
\hline $\mathbf{I} \cdot 0$ & $1 \cdot 4$ & $5 \cdot 5$ & 10 & $I \cdot 4$ & 45 \\
\hline $3 \cdot 0$ & $3 \cdot 3$ & $\mathrm{I} 2$ & 12 & $3 \cdot 5$ & $>60$ \\
\hline
\end{tabular}

* Organisms incubated at $0.3 \mathrm{mg} / \mathrm{ml}$ for $\mathrm{I}$ h at $37^{\circ} \mathrm{C}$ in $30 \mathrm{~mm}$-phosphate buffer $\mathrm{pH} 6.3$ containing $\mathrm{I}$ mMiodoacetamide, then washed twice in distilled water before s.r.c. determination. 


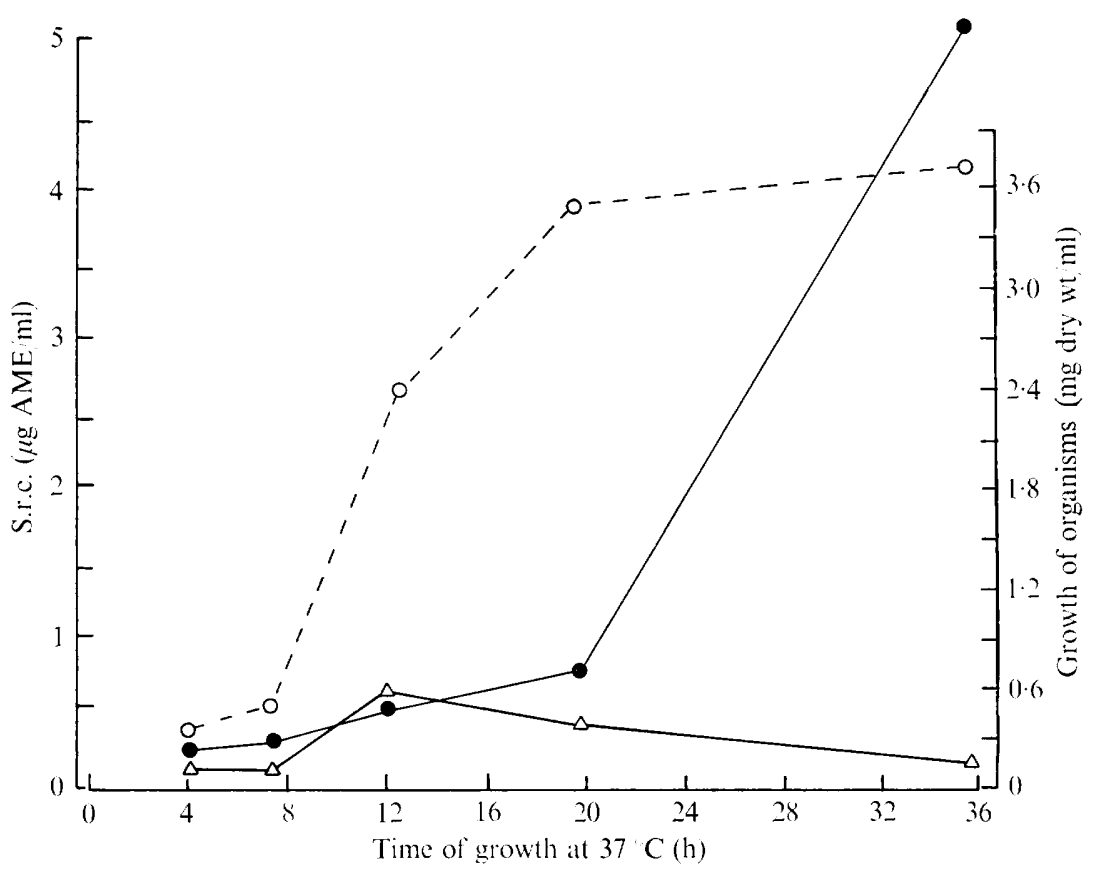

Fig. 2. Variation with phase of growth of AME sensitivity of $C$. albicans organisms and sphaeroplasts. Candida albicans 6406 was grown in YNB medium with $2 \%(w / v)$ glucose at $37{ }^{\circ} \mathrm{C}$; organisms were harvested at times shown; suspensions of organisms $(\bullet)$ and sphaeroplasts $(\triangle)$ were prepared as in Methods and suspended at a density equivalent to $\mathrm{I} \cdot 0 \mathrm{mg}$ dry wt of organisms $/ \mathrm{ml}$ in $0.03 \mathrm{M}$-tris- $\mathrm{HCl}$ buffer $\mathrm{pH}_{7} .5$ containing $0.8 \mathrm{M}$-sorbitol. S.r.c. was determined as in Fig. I.

larger yields of organism and that the resistance of late stationary organisms could increase to values of greater than $60 \mu \mathrm{g} \mathrm{AME} / \mathrm{ml}$. The sensitivity of Candida could thus be varied more than 300 -fold by manipulating the growth time and glucose concentration of the medium.

Figure 2 shows the change in AME sensitivity of organisms and sphaeroplasts derived therefrom after growth in a medium containing an initial glucose concentration of $2 \%$. The organisms show the usual decrease in sensitivity as the culture 'ages'; sphaeroplasts do not show this variation and remain highly sensitive even when derived from organisms grown for $36 \mathrm{~h}$. The 'older' the organisms the more difficult the production of sphaeroplasts proved to be; as described above under Methods, sphaeroplast formation from stationaryphase organisms required a higher concentration of mercaptoethanol and longer digestion with streptomyces enzymes than it did from exponential-phase cells. Sphaeroplasts have been prepared from cells grown for $48 \mathrm{~h}$ and have been found to have an AME sensitivity of $\mathrm{I}$ to $5 \mu \mathrm{g} / \mathrm{ml}$ compared with s.r.c. values of 45 to 60 for the intact organisms: it is doubtful. however, whether all the wall structure had been removed from these resistant organisms,

The relative resistance of late stationary-phase organisms compared with exponential organisms or sphaeroplasts from either could have been due to the presence of antagonistic or non-specific binding substances in the walls, or to increasing impedance to the passage of drug through the wall as the organisms 'aged'. The effect of digesting away the wall could have been due to either or both of these factors. 


\section{Table 3. Effect of wall extracts on sensitivity of Candida albicans to amphotericin methyl ester}

Candida albicans was harvested after growth at $37^{\circ} \mathrm{C}$ for $\mathrm{I} 5$ and $40 \mathrm{~h}$; suspensions of organisms and sphaeroplasts, and enzyme extracts were prepared as described in Methods. Organisms or sphaeroplasts were suspended at a density corresponding to $\mathrm{I} \cdot \mathrm{O} \mathrm{mg}$ dry weight of initial organisms/ $\mathrm{ml}$ in $0.05 \mathrm{M}$-tris- $\mathrm{HCl}$ buffer $\mathrm{pH} 7.5$ containing $0.8 \mathrm{M}$-sorbitol.

\section{Time of growth at $37^{\circ} \mathrm{C}$} (h) I 5

Organisms
Sphaeroplasts

Suspension

Organisms

Sphaeroplasts

Sphaeroplasts

\section{Organisms}

\section{Addition}

None
Enzyme extract of 40 h organisms*
After $30 \mathrm{~min}$ incubation
After $120 \mathrm{~min}$ incubation
After I $80 \mathrm{~min}$ incubation
Sphaeroplast lysate $\dagger$
None
Enzyme extract* (1 $80 \mathrm{~min})$
None
None
Enzyme extract* (I $80 \mathrm{~min})$

S.r.c. ( $\mu \mathrm{g} \mathrm{AME} / \mathrm{ml}$ )

$0 \cdot 12$

0.12

0.25

0.40

0.33

0.07

0.5

$4 \cdot 5$

0.15

$2 \cdot 5$

* Extracts were obtained (as described in Methods) by the use of Streptomyces enzyme preparation incubated for the time shown and organisms or sphaeroplasts then removed by centrifuging; extracts were boiled to inactivate enzymes and an amount corresponding to that obtained from $\mathrm{I} \cdot \mathrm{O} \mathrm{mg}$ dry wt of organisms was added to the Candida suspension for redetermination of s.r.c.

$\uparrow$ The lysate was obtained by osmotic lysis in tris buffer without sorbitol; the amount added again corres sonded to $\mathbf{I} \cdot 0 \mathrm{mg}$ dry $w \mathrm{t}$ of initial organisms.

\section{The presence of antagonistic substances in extracts of stationary-phase cells}

Organisms were harvested after 36 to $40 \mathrm{~h}$ growth at $37^{\circ} \mathrm{C}$, sphaeroplasts prepared, and the material extracted by digestion from the organisms separated and collected. The extracts were boiled to inactivate the streptomyces enzyme preparation and their effect on the AME sensitivity of organisms and sphaeroplasts studied. Table 3 shows that the addition of such an extract from $40 \mathrm{~h}$ organisms significantly increased the resistance to AME of $15 \mathrm{~h}$ organisms. Extracts were prepared from $40 \mathrm{~h}$ organisms incubated with streptomyces enzymes for 30,120 and $180 \mathrm{~min} ; 30$ min extracts were without effect and 180 min extracts were used for the work described below. The $180 \mathrm{~min}$ extract increased the resistance to AME of sphaeroplasts obtained from either 15 or $40 \mathrm{~h}$ organisms - the increase being greater than I6-fold in the latter case. The assumption has been made that digestion with streptomyces enzymes released material from that part of the cell exterior to the cytoplasmic membrane but it is possible that some sphaeroplasts underwent lysis during digestion and that the antagonistic material was released from these. Table 3 compares the antagonism obtained with the extract from a given number of cells with that obtained from the lysate of the same number of sphaeroplasts; the latter was less than the former so that it is improbable that the activity of the extract could be attributed to material released by lysis of a small proportion of the sphaeroplasts.

\section{The nature of the antagonistic material released from stationary-phase organisms}

A bulk preparation made by streptomyces enzyme digestion of approximately $2 \mathrm{~g}$ dry wt of Candida was then fractionated as described under Methods and summarized in Table $\mathrm{I}$. The amount of antagonistic material was assessed at each stage by determination of the 
Table 4. Antagonism of amphotericin methyl ester $(A M E)$ by lipids

The s.r.c. for AME was determined (as in Table 2) with suspensions of C. albicans grown for $15 \mathrm{~h}$ at $37^{\circ} \mathrm{C}$; an a.u. for each lipid was determined; lipids were added in ethanol solution and equal amounts of ethanol were added to controls. The s.r.c. for the experiments A to E was $2 \times 10^{-7} \mathrm{M}-$ $\mathrm{AME}$ and antagonism is expressed in terms of the molar ratio of AME to an a.u. of lipid.

\begin{tabular}{|c|c|c|c|c|c|}
\hline \multirow[b]{2}{*}{ Lipid } & \multicolumn{5}{|c|}{ Antagonism } \\
\hline & Expt A & Expt B & Expt C & Expt D & Expt $\mathbf{E}$ \\
\hline Ergosterol & $0 \cdot 2$ & $0 \cdot 16$ & 0.18 & $0 \cdot 13$ & 0.13 \\
\hline Ergosterol oleate & - & 0.45 & 0.40 & - & 0.37 \\
\hline Ergosterol palmitoleate & - & 0.30 & 0.17 & -- & 0.08 \\
\hline Ergosterol palmitate & - & $0 \cdot 28$ & 0.13 & - & 0.06 \\
\hline Ergosterol stearate & - & 0.17 & - & - & - \\
\hline Cholesterol & 0.07 & - & 0.08 & - & - \\
\hline Cholesterol oleate & $0 \cdot 35$ & -- & - & - & -- \\
\hline Cholesterol palmitate & 0.21 & - & - & 一 & - \\
\hline Glyceryl trioleate & 0.045 & - & - & - & - \\
\hline $\begin{array}{l}\text { Cis, cis-9-I 2-octadecadienoic acid } \\
\text { (linoleic acid) }\end{array}$ & - & - & - & 0.014 & - \\
\hline Cis-9-octadecenoic acid (oleic acid) & 0.019 & - & 0.021 & $0.02 \mathrm{I}$ & - \\
\hline Trans-9-octadecenoic acid & $\cdots$ & - & - & 0.036 & 一 \\
\hline Cis-9-hexadecenoic acid (palmitoleic acid) & - & - & 0.015 & 0.010 & - \\
\hline Hexadecanoic acid (palmitic acid) & 0.013 & - & 0.013 & - & 一 \\
\hline Octadecanoic acid (stearic acid) & - & - & O.0II & - & - \\
\hline Tetradecanoic acid (myristic acid) & - & - & - & 0.007 & $\ldots$ \\
\hline Dodecanoic acid (lauric acid) & - & - & - & - & 0.00 \\
\hline Glyceryl dipalmitate & 0.004 & - & - & -- & - \\
\hline
\end{tabular}

number of a.u. in each fraction. Three separate fractionations were carried out; the number of a.u. obtained in each fraction was averaged and normalized so that the total a.u. in the initial extract is expressed as 100 in Table I. The heated extract was first separated by centrifugation into pellet and supernatant fractions, both of which contained antagonistic material. Up to $90 \%$ of the antagonistic activity was extracted in the lipid fraction on treatment with chloroform-methanol; in all three preparations, an increase in the total a.u. was found on lipid extraction of the pellet fraction. The small amount of active material in the lipid-extracted residues was not precipitated by $80 \%(\mathrm{v} / \mathrm{v})$ ethanol or $100 \%$ saturated ammonium sulphate and no further investigations were carried out on this material. Separation of the lipid extracts into polar and non-polar fractions showed that essentially all the activity was present in the latter. The non-polar lipid fractions were finally separated by t.l.c. into sterol, sterol ester, triglyceride and free fatty acid fractions; antagonistic activity was found in all fractions. In one experiment the amount of lipid in these fractions was estimated and the a.u. $/ \mu \mathrm{g}$ lipid calculated as $0.2,0.15,0.04$ and 0.03 for the sterol, sterol ester, triglyceride and free fatty acid fractions respectively.

\section{Antagonism of AME by pure lipids}

Table 4 shows the antagonistic action of a number of neutral lipids when assessed under conditions similar to those for the study of streptomyces enzyme extracts. In each case the amount of lipid equivalent to I a.u. was determined and related on a molar basis to the concentration of AME used. Gale (1974) found that, although the molar ratio of AME to sterol giving a given degree of antagonism varied from culture to culture, the relative values of those ratios for different sterols remained constant. In I4 experiments carried out over six months, although the molar ratio of AME to ergosterol corresponding to I a.u. varied 


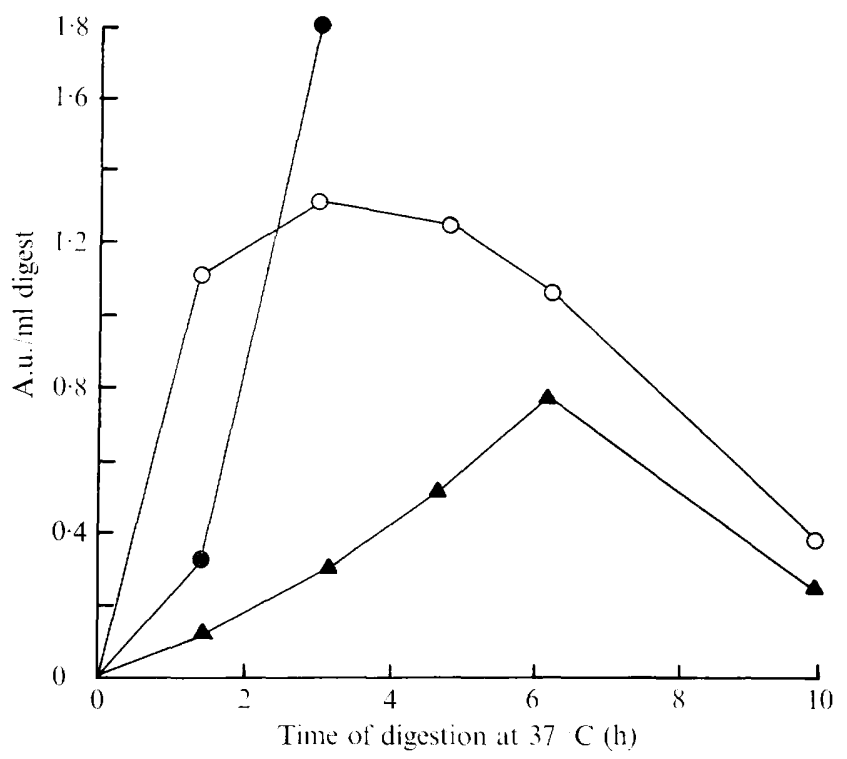

Fig. 3. Release of AME-antagonistic material from $C$. albicans by incubation with streptomyces enzyme preparation. Candida albicans was harvested after $15(\mathrm{O}), 40(\bullet)$ or $45(\Delta) \mathrm{h}$ growth at $37^{\circ} \mathrm{C}$ and digested at $37^{\circ} \mathrm{C}$ with Streptomyces violaceus enzyme preparation after treatment with $0.2 \mathrm{M}$-mercaptoethanol as in Methods (treatment B). Extracts were boiled and assayed for antagonistic action as in Methods.

from 0.34 to 0.13 (mean 0.20 ), the antagonistic action of ergosterol was always between 2 and 3 times greater than that of cholesterol, and a series of sterols always fell into the same relative order of effectiveness. Table 4 shows that certain sterol esters were more effective antagonists than the free sterols, ergosterol derivatives than cholesterol derivatives, unsaturated fatty acid derivatives than the corresponding saturated derivatives, and sterol lipids than non-sterol lipids. Specific lipids fell into the following order of decreasing antagonistic action against AME: ergosterol oleate, cholesterol oleate, ergosterol, cholesterol, triolein, oleate.

\section{Release of antagonistic material from exponential and stationary-phase organisms}

Enzyme digests from stationary-phase organisms were examined for antagonistic material since the sphaeroplasting process reduced their resistance to a low value. However, Fig. 3 shows that antagonistic material was also released from exponential-phase organisms and the rate of release was markedly more rapid than from stationary-phase organisms. After $3 \mathrm{~h}$ digestion more antagonistic material was released from stationary- than from exponentialphase organisms but the difference was not great and, since continued digestion with the streptomyces enzyme preparation resulted in loss of antagonistic activity, all the values must represent a balance between release and destruction of antagonistic substances. Since the analyses given above show that these substances are mainly lipids, wall preparations from exponential- and stationary-phase organisms have been analysed for their lipid content. Wall preparations from $40 \mathrm{~h}$ organisms contained approximately $75 \%$ more total lipid, $25 \%$ more neutral lipid and 30\% more triglyceride (which forms 45 to $50 \%$ of the neutral lipid) than similar preparations from exponential-phase organisms. Ergosterol and sterol esters were found in the preparations and formed $\mathrm{I} \cdot 4$ and $\mathrm{I} \cdot 9 \%$, respectively, of the total lipid; these did not increase in amount with time of growth. It is improbable that an increased 
Table 5. Lipid content of wall preparations from C. albicans grown for $40 \mathrm{~h}$ in media with different initial concentrations of glucose

Candida albicans was grown for $40 \mathrm{~h}$ at $37^{\circ} \mathrm{C}$ in YNB medium $(6.7 \mathrm{~g} / \mathrm{l})$ containing initial concentrations of glucose as below. Cells were harvested and washed twice with distilled water on the centrifuge; the s.r.c. of AME was determined (as Table 2) on a portion, and the remainder used for preparation of cell walls and their analysis as under Methods.

\begin{tabular}{|c|c|c|c|c|}
\hline Initial glucose concn $(\%, w / v)$ & $0 . I$ & 0.3 & $I \cdot 0$ & 3.0 \\
\hline S.r.c. $(\mu \mathrm{g} \mathrm{AME} / \mathrm{ml})$ & $0 \cdot 4$ & $2 \cdot 2$ & $5 \cdot 5$ & $18 \cdot 0$ \\
\hline Total lipid $(\%, w / w$, cell wall $)$ & $3 \cdot 3$ & $3 \cdot 3$ & $4 \cdot 2$ & $2 \cdot 6$ \\
\hline $\begin{array}{l}\text { Neutral lipid: } \\
\% \text { (w/w) cell wall } \\
\% \text { total lipid }\end{array}$ & $\begin{array}{l}2 \cdot I \\
65\end{array}$ & $\begin{array}{l}2 \cdot 2 \\
67\end{array}$ & $\begin{array}{c}3 \cdot 7 \\
89\end{array}$ & $\begin{array}{c}2.0 \\
79\end{array}$ \\
\hline $\begin{array}{l}\text { Sterols: } \\
\%(w / w) \text { cell wall } \\
\% \text { neutral lipid }\end{array}$ & $\begin{array}{l}0.04 \\
2.0\end{array}$ & $\begin{array}{c}0.25 \\
11.4\end{array}$ & $\begin{array}{l}0.2 \mathrm{I} \\
5.8\end{array}$ & $\begin{array}{l}0.12 \\
6.2\end{array}$ \\
\hline $\begin{array}{l}\text { Sterol esters: } \\
\% \text { (w/w) cell wall } \\
\% \text { neutral lipid }\end{array}$ & $\begin{array}{c}0.42 \\
19.6\end{array}$ & $\begin{array}{c}0.22 \\
10.0\end{array}$ & $\begin{array}{l}0.3 I \\
8.6\end{array}$ & $\begin{array}{l}0.19 \\
9 \cdot 3\end{array}$ \\
\hline $\begin{array}{l}\text { Free fatty acids: } \\
\% \text { (w/w) cell wall } \\
\% \text { neutral lipid }\end{array}$ & $\begin{array}{c}0.44 \\
2 \mathrm{I} \cdot \mathrm{I}\end{array}$ & $\begin{array}{c}0.28 \\
12.6\end{array}$ & $\begin{array}{l}0.23 \\
6.2\end{array}$ & $\begin{array}{l}0.13 \\
6.6\end{array}$ \\
\hline $\begin{array}{l}\text { Triglycerides: } \\
\%(w / w) \text { cell wall } \\
\% \text { neutral lipid }\end{array}$ & $5_{58}^{I \cdot 24}$ & ${ }_{60}^{I \cdot 3}$ & $\begin{array}{c}I \cdot 86 \\
50 \cdot 5\end{array}$ & $\begin{array}{c}I \cdot 17 \\
58\end{array}$ \\
\hline
\end{tabular}

lipid content of this magnitude can alone explain the 30- to I00-fold increase in AME resistance that occurred after the culture had entered the stationary phase.

Analyses have also been carried out on the lipid content of wall preparations from Candida grown for $40 \mathrm{~h}$ at $37^{\circ} \mathrm{C}$ in media containing differing initial concentrations of glucose (see Table 2). From the results set out in Table 5, there would appear to be no correlation between the amount of total lipid or any lipid fraction of the walls and the AME sensitivity of the organisms. The only fraction to show any trend was that of the free fatty acids, where organisms of increasing AME resistance showed decreasing fatty-acid content.

\section{Loss of AME resistance by stationary-phase organisms}

Organisms grown in media containing $2 \%$ glucose for 40 to $48 \mathrm{~h}$ may have an AME resistance greater than $40 \mu \mathrm{g} \mathrm{AME} / \mathrm{ml}$ (see Table 2): inoculation of such organisms into fresh growth medium led within 2 to $3 \mathrm{~h}$ to the production of organisms sensitive to less than $0.2 \mu \mathrm{g} \mathrm{AME} / \mathrm{ml}$. Organisms harvested after $40 \mathrm{~h}$ growth were suspended at a density of $0.3 \mathrm{mg}$ dry weight $/ \mathrm{ml}$ in medium $\mathrm{N}$ at $\mathrm{pH} 6.3$ containing $\mathrm{K}^{+}, \mathrm{Na}^{+}$, phosphate, $\mathrm{NH}_{4}{ }^{+}$and I \% glucose. Table 6 shows that after 60 min at $37{ }^{\circ} \mathrm{C}$, the AME resistance of the organisms fell from an initial value of 4.0 to $0.2 \mu \mathrm{g} / \mathrm{ml}$. Incubation in phosphate buffer at $\mathrm{pH} 6.3$ without $\mathrm{NH}_{4}{ }^{+}$or glucose had no effect on the sensitivity. The Table also shows that treatment of the organisms under the conditions used for sphaeroplast preparation (treatment B), but with the streptomyces enzymes omitted, did not result in a large decrease in AME resistance. Table 7 shows the effect of metabolic inhibitors on the increase in sensitivity in the complete medium: iodoacetamide, $N$-ethylmaleimide, dinitrophenol and sodium fluoride all decreased the extent of the increase, while $p$-fluorophenylalanine, puromycin, 5 -fluorocytosine and polyoxin had little or no effect at the concentrations tested. The results in Tables 6 and 7 suggest that the increase in sensitivity was a metabolic effect. However, it was noted that 


\section{Table 6. Loss of AME resistance in stationary-phase C. albicans during incubation in media containing salts and glucose}

Candida albicans was harvested after $40 \mathrm{~h}$ growth at $37{ }^{\circ} \mathrm{C}$ in YNB medium containing $2 \%$ glucose. Expt A: Organisms were washed and suspended at $\mathrm{I} \cdot 0 \mathrm{mg}$ dry $\mathrm{wt} / \mathrm{ml}$ in $0.03 \mathrm{M}$-tris- $\mathrm{HCl}$ buffer pH 7.5 (no sorbitol) for determination of s.r.c. of AME. Further samples were then suspended without shaking at $0.3 \mathrm{mg}$ dry $\mathrm{wt} / \mathrm{ml}$, for $60 \mathrm{~min}$ at $37^{\circ} \mathrm{C}$ in media as below, centrifuged, and resuspended as before for s.r.c. determination. Expt B, 'sphaeroplast procedure': Organisms were treated as for sphaeroplast preparation (see Methods, treatment B) with streptomyces enzyme extract omitted; incubation was for $150 \mathrm{~min}$ at $37^{\circ} \mathrm{C}$, otherwise methods were as for Expt A.

Incubation medium

(Initial value)

Medium S

Medium N

Medium $\mathrm{S}+$ glucose $(2 \%)$

Medium $\mathrm{N}+$ glucose $(2 \%)$

As for sphaeroplast procedure,

less streptomyces enzymes
S.r.c. $(\mathrm{g} A M E / \mathrm{ml})$

$\begin{array}{cc}\text { Expt A } & \text { Expt B } \\ (4.0) & (3.8) \\ 4.0 & - \\ \mathrm{I} \cdot 8 & - \\ 0.9 & - \\ 0.2 & 0.08 \\ - & 3.3\end{array}$

Table 7. Effect of metabolic inhibitors on the loss of AME resistance in $C$. albicans incubated in a salts-glucose medium

Conditions were as for Table 6 , using medium $\mathrm{N}+2 \%(\mathrm{w} / \mathrm{v})$ glucose, with the addition of inhibitors as below during the incubation period.

\begin{tabular}{|c|c|c|c|}
\hline \multirow[b]{2}{*}{ Inhibitor } & \multirow[b]{2}{*}{ Conen } & \multicolumn{2}{|c|}{ S.r.c. $(\mu \mathrm{g} \mathrm{AME} / \mathrm{ml})$} \\
\hline & & Expt. I & Expt. 2 \\
\hline (Initial value) & & $(6 \cdot 5)$ & $(4 \cdot 3)$ \\
\hline None & & 0.3 & 0.3 \\
\hline \multirow{2}{*}{ Iodoacetamide } & I $\mathrm{mM}$ & $>20$ & $9 \cdot 0$ \\
\hline & O.I mM & - & $4 \cdot 3$ \\
\hline$N$-ethylmaleimide & I $\mathrm{mM}$ & $>20$ & - \\
\hline Sodium fluoride & $100 \mathrm{~mm}$ & - & $3 \cdot 7$ \\
\hline \multirow[t]{2}{*}{2,4 -Dinitrophenol } & I $\mathrm{mM}$ & $\mathrm{I} \cdot 2$ & - \\
\hline & $3 \mathrm{~mm}$ & - & $I \cdot 4$ \\
\hline Sodium arsenate & $100 \mathrm{~mm}$ & 0.5 & - \\
\hline Puromycin & $\mathrm{O} \cdot \mathrm{I} \mathrm{mm}$ & - & 0.7 \\
\hline$p$-Fluorophenylalanine & $10 \mathrm{mM}$ & - & 0.9 \\
\hline Polyoxin & $3 \mathrm{~g} / \mathrm{ml}$ & - & 0.7 \\
\hline 5-Fluorocytosine & $0.1 \mathrm{~mm}$ & 0.3 & $\ldots$ \\
\hline
\end{tabular}

incubation with I mM-iodoacetamide or $N$-ethylmaleimide resulted in an increased resistance to AME which, with some cultures, amounted to 5- to 7-fold. Table 2 shows the effect of iodoacetamide treatment on organisms grown for $40 \mathrm{~h}$ in media of different glucose concentration.

Iodoacetamide and $N$-ethylmaleimide are alkylating agents but the specificity of the reaction depends upon the $\mathrm{pH}$ (Gundlach, Stein \& Moore, 1959), binding of SH compounds occurring specifically at mildly alkaline $\mathrm{pH}$ values. Table 8 shows that the AME resistance of the organisms decreases on incubation in phosphate buffer alone at $\mathrm{pH} 7 \cdot 3$ or $8 \cdot 4$, but the presence of iodoacetamide or $N$-ethylmaleimide results in resistance 5 to 7 times greater than that in the control. Dithionitrobenzoate (DTNB) reacts specifically with SH compounds at $\mathrm{pH} 7 \cdot 4$ (Brocklehurst \& Little, 1973) and Table 8 shows that treatment with DTNB again increased the AME resistance compared with the control. The increase was not as great as 
Table 8. AME resistance: effects of $p H$ and sulphydryl-binding agents

Organisms incubated for $60 \mathrm{~min}$ at $37^{\circ} \mathrm{C}$ in medium $\mathrm{S}$ adjusted to $\mathrm{pH}$ values as below, with and without sulphydryl-binding agents as below. S.r.c. determined before and after incubation (no sorbitol). Organisms were washed twice in tris buffer $\mathrm{pH} 7 \cdot 5$ before estimation of AME sensitivity.

\begin{tabular}{lccc}
\multicolumn{1}{c}{ Addition } & \multicolumn{3}{c}{$\begin{array}{c}\text { S.r.c. }(\mu \mathrm{g} \text { AME/ml) } \\
\text { NH during incubation for } 60 \mathrm{~min} \text { at } 37{ }^{\circ} \mathrm{C}\end{array}$} \\
None & $6 \cdot 3$ & $7 \cdot 4$ & $8 \cdot 4$ \\
$\quad$ Initial & $7 \cdot 0$ & $7 \cdot 0$ & $7 \cdot 0$ \\
Final & $6 \cdot 5$ & $2 \cdot 5$ & $1 \cdot 1$ \\
Iodoacetamide (I mM) & 32 & 15 & $6 \cdot 2$ \\
$N$-ethylmaleimide (I mM) & 40 & 18 & $8 \cdot 0$ \\
Dithionitrobenzoate (5 mM) & - & - & $3 \cdot 1$
\end{tabular}

Table 9. Effect of mercaptoethanol and iodoacetamide on the $A M E$ resistance of stationary-phase C. albicans

Conditions were as for Table 6. S.r.c. was determined (no sorbitol) before and after incubation at $37^{\circ} \mathrm{C}$ in medium $\mathrm{S}$, with additions and times as below. Organisms were centrifuged after the first treatment; the pellet was drained and re-suspended as shown for the second treatment; organisms were washed twice in $0.03 \mathrm{M}$-tris- $\mathrm{HCl}$ buffer $\mathrm{pH} 7.5$ before s.r.c. determination.

\begin{tabular}{|c|c|c|c|c|}
\hline \multirow{3}{*}{$\begin{array}{c}\text { Additions to } \\
\text { incubation } \\
\text { medium }\end{array}$} & \multicolumn{4}{|c|}{ Standard release concentration ( $\mu \mathrm{g} \mathrm{AME} / \mathrm{ml})$} \\
\hline & \multicolumn{3}{|c|}{ First treatment } & \multirow{2}{*}{$\begin{array}{l}\text { Second } \\
\text { treatment } \\
(60 \mathrm{~min})\end{array}$} \\
\hline & $\mathrm{omin}$ & $60 \mathrm{~min}$ & I $20 \mathrm{~min}$ & \\
\hline First: & & & & \\
\hline I mM-iodoacetamide & $5 \cdot 5$ & Io & 25 & - \\
\hline $\begin{array}{l}\text { Second: } \\
0.2 \mathrm{M}-\text { mercaptoethanol }\end{array}$ & & $\begin{array}{l}\downarrow \\
\text { (IO) }\end{array}$ & - & 25 \\
\hline First: & & & & \\
\hline 0.2 M-mercaptoethanol & $5 \cdot 5$ & $I \cdot 4$ & $1 \cdot 0$ & - \\
\hline $\begin{array}{l}\text { Second: } \\
\quad \text { I mM-iodoacetamide }\end{array}$ & & $\begin{array}{c}\downarrow \\
(I \cdot 4)\end{array}$ & - & 25 \\
\hline
\end{tabular}

that obtained with iodoacetamide or $N$-ethylmaleimide but this may have been due to DTNB reacting only with SH groups on the surface of the organisms. The reaction between SH and DTNB releases an equivalent of mercaptonitrobenzoate (Brocklehurst \& Little, I973), but colorimetric assay of the coloured material released by reaction with organisms of AME sensitivity between 0.2 and $24 \mu \mathrm{g} / \mathrm{ml}$ showed that, although more mercaptonitrobenzoate was released in the presence of organisms of high AME resistance, there was no direct correlation between the two parameters.

Table 9 shows that incubation of stationary-phase organisms for $\mathrm{I} \mathrm{h}$ at $37^{\circ} \mathrm{C}$ with $0.2 \mathrm{M}$ mercaptoethanol resulted in an $80 \%$ decrease in AME resistance, while incubation with I mM-iodoacetamide before or after treatment with mercaptoethanol, increased resistance by 4 to 18 -fold. Dithiothreitol had an effect similar to that of mercaptoethanol. Mercaptoethanol did not decrease the resistance of organisms first treated with iodoacetamide. It would appear that masking SH groups led to increased AME resistance. The action of mercaptoethanol could have been due to a reduction of disulphide links in the cell surface but R. Davies (private communication) found that mercaptoethanol released a wide variety of substances from the surface structures of Saccharomyces fragilis and C. albicans, so that the effect could have been more complex than simple reduction. Attempts were therefore made 


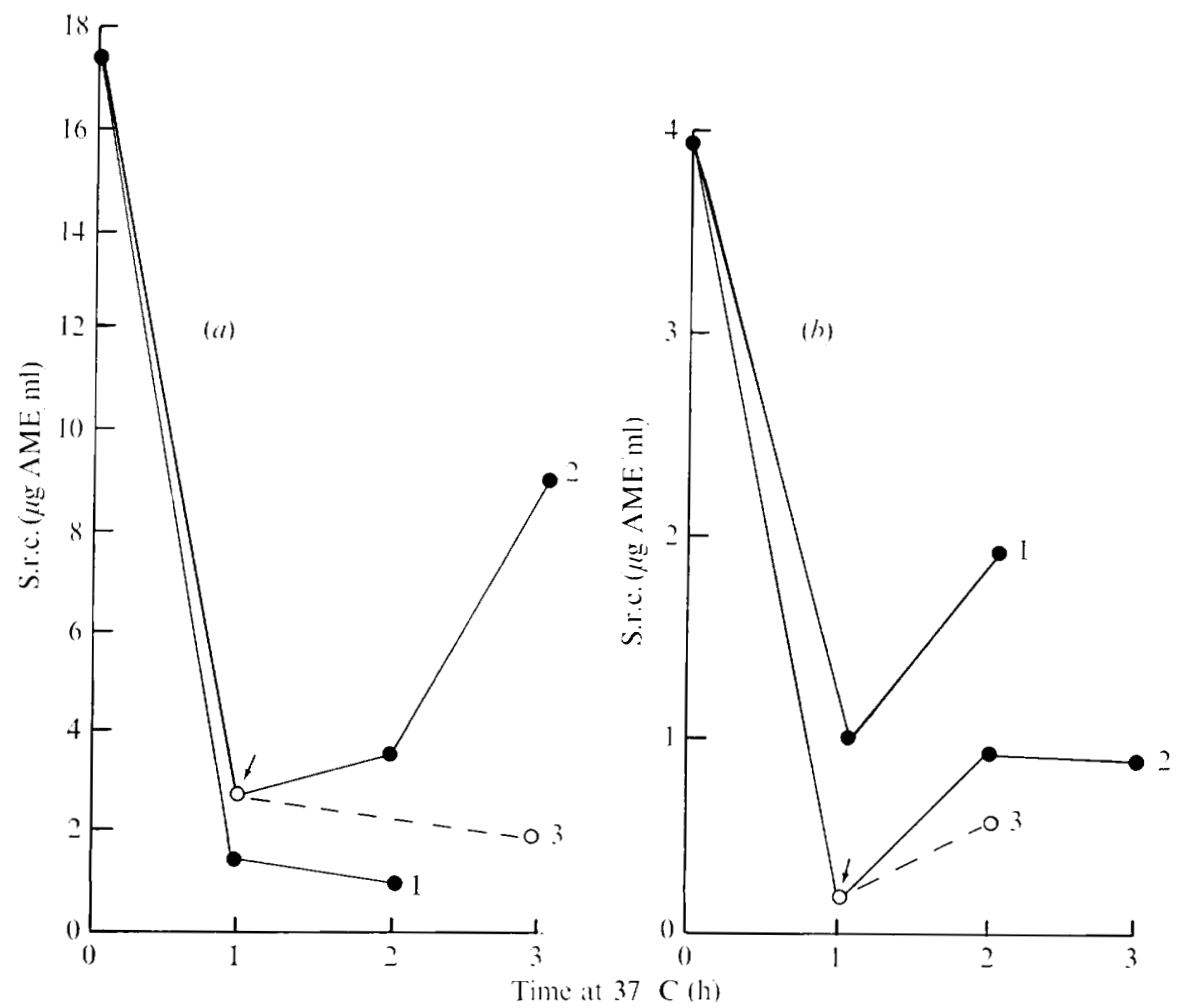

Fig. 4. Effects of oxygen and mercaptoethanol on the AME sensitivity of stationary-phase cultures of C.albicans. Candida albicans was grown for $40 \mathrm{~h}$ at $37{ }^{\circ} \mathrm{C}$ in YNB medium containing an initial concentration of $(a) 2 \%$ or $(b) 0.3 \%$ glucose. Cells were harvested, washed twice in distilled water, and s.r.c. of AME determined at a suspension density of $\mathrm{I} \cdot 0 \mathrm{mg}$ dry $\mathrm{wt} / \mathrm{ml}$ in $0.3 \mathrm{M}$-tris- $\mathrm{HCl}$ buffer pH 7.5. For treatment, organisms were suspended at $0.3 \mathrm{mg}$ dry $\mathrm{wt} / \mathrm{ml}$ in phosphate medium $\mathrm{S}$ pH 6.3 at $37^{\circ} \mathrm{C}$; curve 1 , bubbled with $\mathrm{O}_{2}$; curve $2,0.2 \mathrm{~mm}$-mercaptoethanol for $\mathrm{I} \mathrm{h}$, organisms centrifuged and resuspended in medium $S$ (at arrow) and bubbled with oxygen; or curve 3 , as a static suspension in an open vessel. At the points as shown, the organisms were centrifuged, washed twice with distilled water and resuspended at $1.0 \mathrm{mg} / \mathrm{ml}$ in $0.03 \mathrm{M}$-tris- $\mathrm{HCl}$ buffer $\mathrm{pH} 7.5$ for determination of s.r.c.

to increase the resistance of mercaptoethanol-treated organisms by a second incubation in the presence of mild oxidizing agents. Incubation for $60 \mathrm{~min}$ at $37^{\circ} \mathrm{C}$ with $0 \cdot 1$ M-oxidized glutathione, a saturated solution of cystine, or bubbling with oxygen increased the resistance of such organisms by 33,25 and $40 \%$, respectively. Fig. $4(a)$ shows that bubbling oxygen through a suspension of stationary phase Candida reduced the AME resistance from 17.5 to $\mathrm{I} \cdot 5 \mu \mathrm{g} / \mathrm{ml}$ in $60 \mathrm{~min}$ while treatment for the same time with $0.2 \mathrm{M}$-mercaptoethanol reduced the value of $2.5 \mu \mathrm{g} / \mathrm{ml}$. The organisms were then centrifuged and resuspended in medium $\mathrm{S}$; the sensitivity of the static suspension increased further during $2 \mathrm{~h}$ at $37^{\circ} \mathrm{C}$, whereas that of a parallel suspension bubbled with oxygen fell to $9 \mu \mathrm{g} A M E / m l$. The effect of bubbling $\mathrm{O}_{2}$ through mercaptoethanol-treated organisms was not consistent. Oxygen appears to have two opposing effects: promoting metabolism of reserves in fresh organisms (giving a decrease in AME resistance), and oxidizing mercaptoethanol-treated organisms (giving an increase in resistance). Attempts were made to reduce the first effect by the use of inhibitors or by reducing the glucose content of the growth medium. No useful results were obtained 


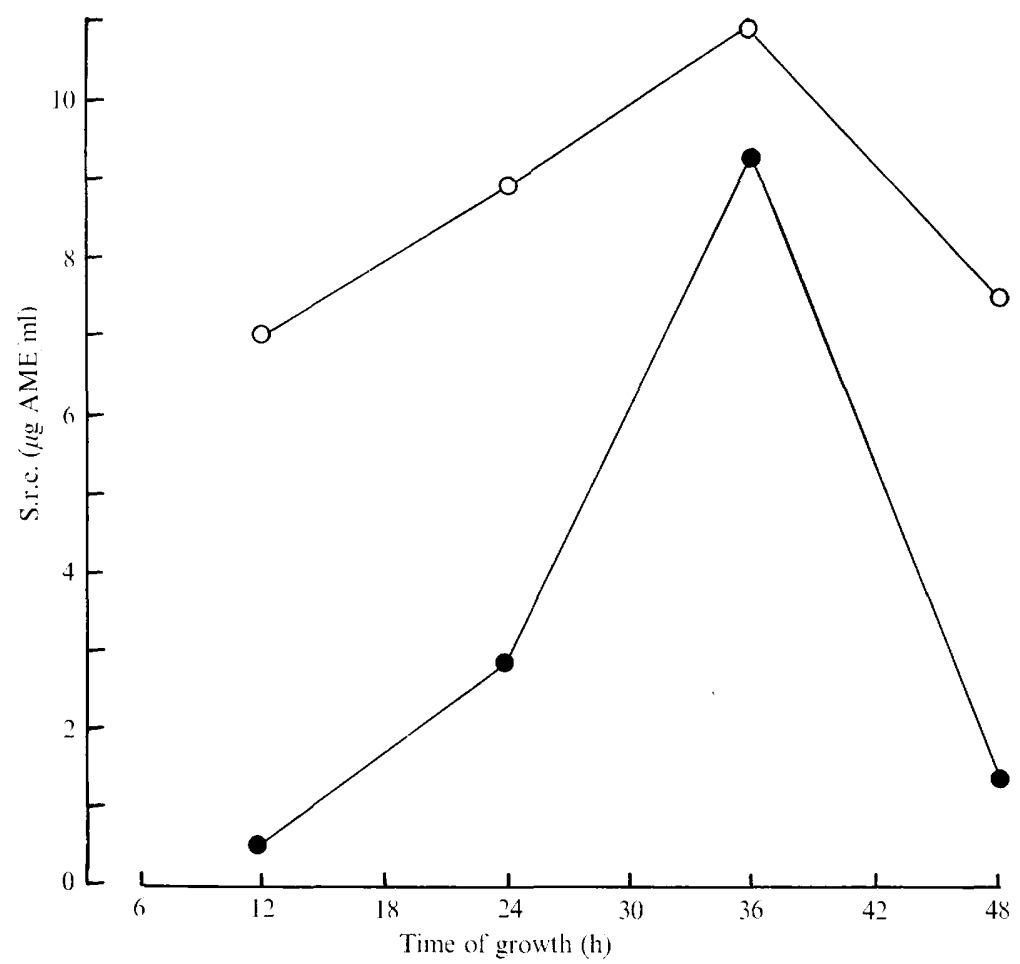

Fig. 5. Action of treatment with iodoacetamide on AME resistance of $C$. albicans. Conditions were as for Fig. I. Suspensions of organisms were divided into two; one portion (O) was used for the determination of the s.r.c. of AME as usual, the second portion (O) was incubated at a density of $0.3 \mathrm{mg}$ dry $\mathrm{wt} / \mathrm{ml}$, for $\mathrm{I} \mathrm{h}$ at $37^{\circ} \mathrm{C}$ in phosphate medium $\mathrm{S} \mathrm{pH} 6.3$ containing $\mathrm{I}$ mm-iodoacetamide, and the organisms were centrifuged, washed twice in distilled water and resuspended at $1.0 \mathrm{mg}$ dry $\mathrm{wt} / \mathrm{ml}$ in $0.03 \mathrm{M}$-tris- $\mathrm{HCl}$ buffer $\mathrm{pH} 7 \cdot 5$ for s.r.c. determination.

with inhibitors but Fig. 4(b) shows that, with organisms grown in medium with an initial glucose concentration of $0.3 \%$, mercaptoethanol treatment gave a greater reduction in AME resistance than bubbling $\mathrm{O}_{2}$, while further bubbling with $\mathrm{O}_{2}$ after resuspension increased the resistance in both suspensions - that of the mercaptoethanol-treated organisms increasing $7 \cdot 5$-fold in $60 \mathrm{~min}$.

\section{Effect of iodoacetamide on AME-sensitivity of Candida harvested at different phases of growth}

Tables 2, 7 and 8 show that the AME resistance of stationary-phase organisms can be markedly increased by incubating the organisms in suspension with iodoacetamide. Figure 5 shows the effect of iodoacetamide treatment of organisms harvested from a culture at the beginning of, and during, the stationary phase. Three experiments of this nature were carried out and, although differing in the quantitative variations, showed the following: (i) Iodoacetamide sometimes produced a large increase (amounting to 20 to 30 -fold in some instances) in the AME-resistance of organisms harvested in the late exponential or early stationary phases of growth. (ii) As incubation in the late stationary phase continued, AME resistance increased and the effect of iodoacetamide decreased until, after about $36 \mathrm{~h}$ in media containing an initial glucose concentration of $0 . \mathrm{I} \%$, iodoacetamide sometimes had little or no effect on AME resistance. (iii) On prolonged incubation in the stationary phase, 
AME resistance decreased again and iodoacetamide recovered its effect, although the resistance of organisms with or without iodoacetamide treatment was less than the maximum value obtained after $36 \mathrm{~h}$ growth.

\section{DISCUSSION}

Amphotericin and its methyl ester can be bound by sterols and other hydrophobic lipids. The changes brought about by the drug in membrane permeability are believed to be due largely, if not entirely, to hydrophobic interactions with membrane sterols (Gale, 1973) but the work described above shows that the effect of the drug can also be affected by the presence, nature and amount of other neutral lipids in the surface layers of the organisms. Gale (1974) found that $C$. albicans exposed to AME showed a progressive increase in $\mathrm{K}^{+}$ permeability; when organisms were removed from drug solution and resuspended in the absence of drug, the rate of $\mathrm{K}^{+}$release continued to increase linearly, but this increase was largely prevented by the presence of ergosterol in the suspending medium. Similar results (unpublished) have been obtained when drug-treated organisms were resuspended in the presence of cysteine, which destroys AME (Weis \& Levine, I972). In neither case has the damage existing at the time of removal of the organisms from drug solution been reversed during the period (up to $30 \mathrm{~min}$ ) of the experiments. An explanation of these results could be that AME is initially taken up by the organisms at sites other than membrane sterols and that redistribution then takes place so that the drug migrates to the membrane from 'nonspecific' sites after removal of the organisms from drug solution. From the results described above, it seems probable that neutral lipids, including sterols and sterol esters, in the wall act as such non-specific binding sites. The binding of AME to membrane sterols would then take place by two routes: direct passage from the external medium to the membrane without impedance by the wall structure, and an indirect route with wall lipids acting as intermediate binding sites. AME bound by membrane sterols cannot be removed rapidly, but that fraction bound, for example, by wall triglycerides would redistribute in favour of sterols with a higher binding affinity. In organisms exposed to AME and then resuspended in the absence of drug, AME bound by wall triglycerides would move into the membrane and give rise to further damage. If the organisms were resuspended in a medium containing ergosterol some at least of the non-specifically bound drug would distribute into the medium and further damage to the membrane thereby be reduced.

If this hypothesis represents the situation in growing organisms, then the sensitivity of the cell as a whole would vary according to the rates of access of AME to membrane sterols by the two routes. Thus an increase in the neutral lipid content of the wall would increase the non-specific binding of the drug and decrease the sensitivity of the organism as a whole. The greater sensitivity of sphaeroplasts than intact cells in the stationary phase, and the action of lipid extracts of walls in increasing the resistance of the sphaeroplasts, are findings qualitatively in favour of this suggestion. The marked changes in AME sensitivity during the stationary phase when cultures are grown in limited glucose (Fig. I) would accord with a build-up followed by breakdown of non-specific binding substances. However, the large increases in AME resistance that take place during the stationary phase are not correlated with commensurate increases in wall lipids or marked alterations in the composition of the lipid. The 'older' the organisms, the longer it takes to extract the lipids from, and the higher the thiol concentration necessary for the digestion of, the walls by streptomyces enzymes. This suggests that the wall structure is more tightly cross-linked, and the lipid more rigidly enclosed in 'old' than exponential-phase organisms. 
AME resistance in stationary-phase Candida could be increased several-fold by treatment with SH-alkylating agents, and decreased by reduction with mercaptoethanol, dithiothreitol or the metabolism of glucose or endogenous reserves. Thus there is evidence that SH groups in the surface and wall are important factors in determining AME sensitivity, and the formation or rupture of disulphide cross-links in the cell wall could play a major role in the changes of sensitivity that take place during prolonged stationary-phase culture. The hypothesis set out above could accommodate these findings if the access of AME to membrane sterols by the direct route were dependent on the wall structure. The direct route would form the main access in exponential organisms, whereas a more highly cross-linked structure in stationary-phase organisms would impede direct access so that the drug reached the membrane after intermediate binding to non-specific sites in the wall.

This work was supported by a grant from the Medical Research Council.

\section{REFERENCES}

BrockLehurst, K. \& LittLe, G. (1973). Reactions of papain and of low molecular weight thiols with some aromatic disulphides. Biochemical Journal $\mathbf{1 3 3}, 67-80$.

Elorza, M. W., Munroz-Ruiz, E. \& Villanueva, J. R. (1966). Production of yeast cell wall lytic enzymes on a semi-defined medium by a Streptomyces. Nature, London 210, 442-443.

GaLe, E. F. (1973). Perspectives in chemotherapy. British Medical Journal iv, 33-38.

GALE, E. F. (1974). The release of potassium ions from Candida albicans in the presence of polyene antibiotics. Journal of General Microbiology 80, 45I-465.

Gundlach, H. G., Stein, W. H. \& Moore, S. (1959). The nature of the amino acid residues involved in the inactivation of ribonuclease by iodoacetate. Journal of Biological Chemistry 234, 1754-1760.

Hammond, S. M. \& KLIGER, B. N. (1974). Studies on the role of the cell wall of Candida albicans in the mode of action of polyene antibiotics. Proceedings of the Society for General Microbiology I, 45.

HeINEN, W. \& DE VRIES, H. (1966). A combined micro- and semi-micro colorimetric determination of long chain fatty acids from plant cutin. Archiv für Mikrobiologie 54, 339-349.

Kunsis, A. \& Beveridge, J. M. R. (I960). Preparation and certain physical properties of some plant steryl esters. Journal of Organic Chemistry 25, I 209-I 219.

Moore, P. R. \& BaumanN, C. A. (1952). Skin sterols. I. Colorimetric determination of cholesterol and other sterols in skin. Journal of Biological Chemistry 195, 615-62I.

Vandenheuvel, F. A. \& Sallycourt, A. (1968). Reference high-efficiency nonpolar packed columns for the gas-liquid chromatography of nanogram amounts of steroids. I. Retention time data. Journal of Chromatography 38, 439-459.

Van Handel, E. \& Zilversmit, D. B. (1957). Micromethod for the direct determination of serum triglycerides. Journal of Laboratory and Clinical Medicine 5o, I 52-I 57.

Vorbeck, M. L. \& MarinetTI, G. V. (I965). Separation of glycosyl diglycerides from phosphatides using silicic acid column chromatography. Journal of Lipid Research 6, 3-6.

WeIS, M. R. \& LEVINE, H. B. (1972). Inactivation of amphotericin B by reducing agents: influence of growth inhibition of Candida albicans and lysis of erythrocytes. Sabouraudia 1o, I32-142.

Wells, M. A. \& Dittmer, J. C. (1963). The use of Sephadex for the removal of non lipid contaminants from lipid extracts. Biochemistry 2, I259-1263. 